\title{
Ticks of genus Ixodidae: bioecological mechanisms of adaptation to environmental conditions, medical and epidemiological significance
}

\author{
L. Ya. Fedonyuk, I. B. Pryvrotska*, S. S. Podobivskyi, O. Yu. Rujytska, \\ Ya. S. Stravskyy, S. V. Zhyhalyuk
}

\author{
1. Horbachevsky Ternopil National Medical University, 1, Freedom Square, Ternopil, 46001, Ukraine \\ Experimental Station of Epizootology of the Institute of Veterinary Medicine of the \\ National Academy of Sciences of Ukraine, Rivne, Ukraine \\ *Corresponding author E-mail:pryvrotskaib@tdmu.edu.ua
}

Received: 01.11.2020. Accepted 10.12.2020

\begin{abstract}
Considering the geographical position of Ukraine, which is located on the border of several physical and geographical zones, the country has a significant variety of parasitic invertebrates and requires constant monitoring in the current integration conditions. Nowadays climatic changes and anthropogenic effect have an impact on ecosystems organization and cause the incidence of transmissible diseases, including tick-borne infections. In order to prevent the spread of pathogens, there is a necessity to analyze modern data of Ixodidae genus ticks, as components of natural and focal humans and animals diseases, their ecological features, behavioral responses, features of biotopic spread, biological patterns, their epidemiological significance. Our review analysis revealed that all stages of tick development depend on three major natural factors: temperature, humidity, duration of the photoperiod, and the presence of a host. Particularly important is the combination of the first two factors that determines the occurrence of two peaks of the number of ticks in April - May and in August September, the last is less extended. At this time of year the nymphs and imago density increases and their infectious agents rate is increased too. The study of the epidemiological condition proves the fact that nymphs and imago of $I$. ricinus are equally infected with the most common pathogens of infections: Borrelia burgdorferi sensu lato (s/)and Borrelia miyamotoi, rickettsiae bacteria (Anaplasma phagocytophilum), flaviviruses (tick-borne encephalitis virus and deer tick virus) and the protozoans (Babesia microti, Babesia duncani, Babesia divergens and Babesia venatorum). Often there is a different combination of these pathogens in the one tick. The infectious agents rate have an impact on the ticks behavior differences in the feeding duration, increasing ticks bites frequency, decreasing of blood feeding, and a prolongation of the life cycle. Therefore within the transboundary territories the urgent control of agents and vectors of infectious and invasive animals and humans diseases is required, studying changes of migrant thermophilic species habitats geography, and systematic measures for the prevention of parasites implementation is needed.
\end{abstract}

Key words: I. ricinus, I. persulcatus, Lime borreliosis, Borrelia ssp., A. phagocytophilum, babesia, rodents.

\section{Introduction}

Ixodic mites (family Ixodidae series Parasitiformes) are a relatively small, taxonomically isolated group of obligate, temporary, often specific, blood-bearing arthropods - parasites of terrestrial vertebrates, mainly mammals and birds (Gazzavi-Rogozin et al, 2018). The taxonomy of this taxonomic group is quite complex. The world fauna of ixodids includes about 800 species belonging to 2 subfamilies and 14 genera. The fauna of Ukraine is represented by 32 species (Akimov, 1997). The ticks of the Ixodidae family, as blood-sucking ectoparasites, are carriers of many viral, rickettsial, bacterial and protozoal diseases of animals and humans, and the epidemic value is due to the constant presence as components of persistent natural foci of infections (Gazzari et al., 2017). The medical and social importance of ixodic ticks is steadily increasing, sufficiently as an example, to lead to tick borne disease (Lyme disease). The disease was first linked to ticks in 1975 in the United States, and in 1982 a pathogen was isolated. The disease was limited to the territories of North America. But since the late 80's it has been expanding in Europe and Asia. Not the exception is Ukraine, where over the last years there has been a tendency to increase the incidence of Lyme borreliosis. In addition, in the Western Region, located within the forest-steppe and Mixed Forest zones, characterized by sufficient humidity and optimum temperature for the pathogenic circulation, tick-borne encephalitis and (Gazzavi-Rogozin et al., 2018, Fedonjuk et al., 2018).

The constant interest in the study of fauna of ixodic mites, the considerable number of scientific publications devoted to various aspects of their morphology, physiology, biology, is explained by the significant epidemiological significance of acarids.

The goal of the work. To analyze the literature data on the prevalence of ticks of the family Ixodidae (Murray, 1877), as components of natural and focal diseases of humans and animals, their ecological characteristics, behavioral responses, features of biotopic distribution, biological patterns, their epidemiological and medical significance. 


\section{Results and Discussion}

It is known that the main components of the natural zoonotic focus are 1) pathogen, 2) animal reservoirs, 3) vector, 4) spatial "center of the center", 5) favorable environmental conditions. Mites of the genus Ixodes (Latreille, 1795) are prevalent mainly in temperate regions within the Holarctic (Diuk-Wasser et al., 2016). Four of these are of major epidemiological importance as carriers of the vast majority of human pathogens and their habitats are located in densely populated areas, namely $1 x$ odes pacificus (Cooley \& Kohls, 1943) mainly found along the Pacific coast of the United States; Ixodes scapularis (Say, 1821) in the northeast, southern USA; Ixodes ricinus (L., 1758) throughout Europe, parts of northern Africa, Turkey and the Caucasus; Ixodes persulcatus (Schulze, 1930) is widespread in northwestern Europe and the Pacific coast of Asia. Being in different ecological conditions, each type of tick has acquired in the course of evolution its complex of adaptations, which allows it, on the one hand, to successfully adapt to specific habitats, and on the other - to successfully find a host.

Although many factors influence the etiology of ticks, elemental behavioral acts (EPAs) depend primarily on environmental conditions and environmental factors. The mites have a characteristic temperature optimum and humidity regime of the surrounding air. The latter is the most important regulatory factor (McClure \& Diuk-Wasse 2019). So, for I. ricinus, as for any hematophagus, finding a host-animal is crucial. Equally important is the additional need that drives behavior and life cycle maintaining a water balance. Compared to life expectancy, the direct parasitization of ixodide is short-lived: several blood clots, each occurring over several days. In search of the right host, distinguished by a combination of CO2 and volatiles (Berret \& Voordouw 2015), mites in adverse humidity conditions abruptly interrupt the search and migrate to soil litter for rehydration, reducing the chances of finding feed. Herrmann \& Gern 2015). I. ricinus, like other terrestrial arthropods, is moisture dependent and needs to maintain a homeostasis of its water balance in a relative humidity environment of $86 \%$ to $96 \%$. If the relative humidity is below this threshold, there is a need to minimize moisture loss, maximize the active use of atmospheric water vapor, or shorten the stay in "uncomfortable". Particularly vulnerable are mite larvae compared to nymphs and imago, and adult forms are less vulnerable to changes in moisture than nymphs. The lower resistance to dehydration observed in the juvenile stages of development, compared to adults, is probably related to their smaller size, lower water content, and larger surface area to volume, which causes proportionally greater water loss. The greatest amount of moisture by ticks is lost during the active search phase, less is due to the passive waiting of the host on plants. At this time, of course, the metabolic processes associated with the consumption of its reserves are activated (Rosendale, 2017). Also, slight evaporation of water occurs through the respiratory system and the covers, despite the fact that the cuticle is a fairly good insulator.

Therefore, the ticks have a limited moisture balance during the activity, after which they cease to respond to the stimuli characteristic of the host, and migrate to shelter or litter. While in storage, the ticks replenish moisture in the body, due to the surrounding, more saturated with humid air. Due to the special substances contained in the salivary glands of ixodide, there is an active absorption of water vapor and its translation into the body's structures. The decisive role of litter in maintaining the life of ticks of the genus Ixodes was also found in determining the settlement of ticks in urban parks, gardens and squares, where the presence of litter is a prerequisite to settle down and maintain its abundance.

At the same time, air temperature is also a determining factor in the activity of mites. Temperature has a direct and indirect effect on arthropod physiology. It determines the rate of ontogeny, life expectancy and fertility of the imago, gluttony and mobility. Active life of poikilothermic animals is possible only within a certain temperature range, which may be different in different species. Experimental data show that with increasing temperature, the duration of development gradually decreases, with a certain range of temperatures reaches a minimum, and with a further increase in temperature may again increase. That is, by the influence on the organism of cold-blooded arthropods, in the natural populations of our region, the temperature range of existence (the sum of the effective temperatures) can be divided into the following termorhythms:

- threshold initial temperature, the excess of which triggers ontogeny (exit from anabiosis, development, transformation);

- temperature regime is sufficient for active life;

- zone of comfort for kind of temperatures;

- extremely high and low temperatures;

- Threshold end temperature leading to diapause, sterility or death. Of course, this limiting factor is crucial, but not the only one. What matters is the length of the "temperature day", the sharpness and frequency of temperature changes, the duration of the maximum and minimum temperatures.

Of course, it is necessary to take into account the geographical factor of change of temperature background. For example, in the northern Iberian Peninsula I. ricinus is usually active in February-March and September-October, and in the more southern regions in April-May (Remesar et al., 2019), which is temperature dependent. In the spring, I. ricinus is active when the daily average temperature ranges from $7^{\circ}$ to $24^{\circ} \mathrm{C}$, whereas in the summer months the activity decreases. In Ukraine, the averaged field survey results of recent years also indicate two annual species peaks, which nevertheless occur in April and AugustSeptember.

In recent decades, significant climatic changes have been reported in the world, which in turn may have an impact on the geographical spread of ixodic mites. The high air temperature in the spring and autumn continues the growing season and the season during which I. ricinus develops. Accordingly, the activity of vertebrate mite vertebrates is also prolonged, enabling the mites to occupy larger territories, which may be related to the significant capacity for phenotypic changes of different generations of mites (Gilbert et al., 2014). Climate change allows prolonged seasonal activity due to mild winters. Plus temperatures allow them not to fall into a state of anabiosis, for a long time to be active, waiting for the cold on the host. At favorable temperatures, the syntantropization of acaride biotopes is faster. Bringing them to urban areas is carried out with wild animals, synanthropic rodents, cattle, dogs, humans, birds. There is a gradual development of areas of open city territory favorable for habitat mites - large forest park areas, territorially connected with forest areas in the vicinity of the city. Under 
these conditions, new synanthropic populations of ixodic mites are formed, which include all stages of their development, which is the criterion of syntanthropization.

According to the scientists of the Experimental Station of epizootology of the Institute of Veterinary Medicine of the National Academy of Sciences of Ukraine, under the constant "temperature records" 2017-2019, ecological adaptations of ixodids and their phenology have undergone a number of changes. Exit from the winter diapause of dominant species recorded in the third decade of February, although individuals occur throughout February: blood-sucking ticks at high temperatures are longer active, wait for the cold on the host. Thus, region-specific ixodids: Ixodes risinus, I. persulcatus caused the spread of pyroplasmosis of dogs, which were diagnosed in acute form even in December, and since mid-February - constantly). Dermacentor pictus larvae have been recorded since the third decade of April. Whereas in the previous years, the exit from the winter diapause of pubescent ixodids in the Polesie zone occurred in the second decade of April, and in the Forest-steppe zone - from the end of March.

Also distinguishing features are the prolongation of the peak activity of ixodid, in agrocenoses for the 2 spring months: AprilMay and the absence of a second peak in numbers in nymphs and imago. Larval stages typically had two peaks, although the second, usually August, peak is less intense and accounts for September, which can also be attributed to abnormal heat and no mid-summer rainfall (Fedonuk et al., 2019). The urban biotope in the imago also recorded two peaks, indicating that the conditions of urban biotopes are sufficient animals to provide energy for the needs of embryonic and post-embryonic development of acarids, as well as to participate in the spread of ticks: rodents, insects, insects, insects yasoid.

The first occurrence of pubescent ixodids in biotopes is noted at an average air temperature of $-4.5^{\circ} \mathrm{C}$. Output from the litter is observed on days when its average temperature reaches $+6.6^{\circ} \mathrm{C}$ and air $+5^{\circ} \mathrm{C}$. Mass activity is observed since the beginning of April, average temperature $+15,0 \pm 0.1^{\circ} \mathrm{C}$, humidity $81.9 \pm 0.9 \%$

Thus, temperature, humidity, and duration of the photoperiod determine the duration and quality of life of the mite (Ostfeld \& Brunner 2015). Particularly important is the combination of the effects of the first two environmental factors. According to the scientists of the State Institute of Epizootology of the Institute of Epidemiology of the National Academy of Sciences of Ukraine, extreme limitation or excess moisture, even at favorable temperatures $\left(15-30{ }^{\circ} \mathrm{C}\right)$, led to numbness - temperature "shock" acarid, as well as deaths, which occurred at $+38^{\circ} \mathrm{C}$. and $95 \%$ humidity. And blood-saturated females of Ixodes risinus, with a decrease in humidity up to $35 \%$ and a constant temperature of $35^{\circ} \mathrm{C}$, lay unfertilized eggs.

Some EPA behaviors are common to all types of ixodic mites, regardless of habitat conditions. The most characteristic are the following: out of standby, out of active standby, scanning movements, attachment movements, locomotion into the contact area, contact. One of these obligatory specific coordinated sequences of movements is "return to cover" to protect against adverse environmental conditions. Such locomotion is characteristic of mites with a passive and active way of finding a feeder. The ticks of the genus Ixodes have no eyes, therefore, to focus on the host, they primarily use the organs of chemoreception, as the most selective in biotopes with rich vegetation. Some representatives of this genus (I. persulcatus, I. ricinus) rise to low plants for the expectation of the host. The host's passive expectation of these ticks is combined with an active search for places where the likelihood of meeting is higher. Horizontal migration (van Duijvendijk et al., 2017) is carried out by weak chemical signals from the regular passage of animals and residual odors on trails and forest roads. Ixodic mites are able to accurately move towards the source of episodic odor, without responding to soil vibration caused by moving animals.

The energy needs of ticks at all stages of development are provided by the blood of vertebrates. As shown by studies in previous years, despite the fact that proteins are the main organic component of blood, predominantly the energy recovered is converted to lipids and stored in epithelial cells, the midgut, and diffusely in various internal organs of the tick. It has been proven that mites in arid conditions use twice as many lipids as those living in conditions of higher humidity. However, as shown by studies (Romashchenko, 2012), nymphs of /. scapularis and /. persulcatus infected with Borelia are less sensitive to lack of moisture than uninfected ones.

Recent studies have revealed changes, behavioral responses, and phenology of vector-borne ticks that occur under the influence of pathogens. Such manifestations are differences in the duration of individual elementary behavioral movements, an increase in the frequency of bites, a decrease in the blood-sucking time, and an extended life cycle. The major role in ensuring the life cycle of ixodide is played by the adult phase behavior. It aims to preserve the life of the imago and to ensure the reproduction and prosperity of the species. The behavior is always related to living conditions and reflects the level of mite adaptability. Without the development of behavioral adaptations aimed, moreover, at ensuring the parasite's proper encounter with the appropriate host, all other cyclic transformations are impossible.

One of the little-studied mechanisms for the adaptation of ixodic mites to environmental conditions is the interaction with pathogens - viruses and bacteria. Yes, I. scapularis infected with Anaplasma phagocytophilum (Foggie, 1949) is more likely to survive in lower temperatures because anaplasm induces the synthesis of glycoproteins that function as antifreeze and protect mites from low temperatures, inhibiting apoptosis by inhibiting apoptosis. infection with ticks, however, does not affect their nutrition and reproduction process (de la Fuente et al., 2016) It is also known that Borelia and encephalitis virus infected with /. ricinus and /. scapularis survive better in high temperatures and low humidity (Cabezas- Cruz et al., 2017). The mechanism of these changes is not yet sufficiently disclosed, but there is a hypothesis that borelia can alter the metabolism of mite organs involved in water metabolism. Similar to the effect of anaplasm, borelia also alter the expression of one of the salivary gland genes in /. scapularis (Cotté et al., 2014). Obviously, borrels can modify the expression of genes in ticks under different temperature conditions, which can to some extent alter the metabolism, increase the activity and resistance of infected ticks to adverse conditions, and this also contributes to the spread of the pathogen in the environment (Popitsch et al., 2017). it is already known that impaired expression of the p47 gene contributes to the growth of salivation of I. scapularis by Lyme disease agents (McClure Carrolla et al., 2019). 
Climate change and anthropogenic impacts are leading to ecosystem shifts and an increase in the reported incidence of transmissible diseases caused by X-ray mites. Thus, over the last decade, the incidence of Lyme disease caused by the Borrelia burgdorferi s.l. complex has increased worldwide, including in Western and Eastern Europe. The spread of ixodic mites has been shown to be associated with the migration of hosts, including rodents (Korenberg et al., 2015). Another important factor affecting the eco-geography of mites is the anthropogenic factor. Consequences of human activity are diversified, this is an increase in agricultural land and penetration into forested areas, and the use of agrochemicals, and a decrease in the species composition of large vertebrate fauna and, as a result, overwhelming feeding on rodents (Cayol et al., 2018).

There is also a multi-vector mechanism for the receipt and transmission of tick borne pathogen by ixodes. Spirochete Borrelia burgdorferi s.l. it is transmitted by ticks and causes diseases - human Lyme borreliosis. In the bacterial complex of $B$.burgdorferi s.I. includes several subspecies (genomic species). Together with B. afzelii, B. garinii and B. burgdorferi sensu stricto (s.S) they are the main agents of Lyme borreliosis. The prevalence of $B$. afzelii is mainly diagnosed by skin manifestations. $B$. garinii is considered the most neuropathogenic, and B. burgdorferi s.s. often causes rheumatoid arthritis. B. afzelii forms parasitic complexes mainly with rodents, whereas B. garinii forms with birds (van Duijvendijk et al., 2015). According to WHO, Lyme borreliosis is the most common zoonosis in the northern hemisphere (Feria-Arroyo et al., 2014). It is known that the basic vector of Lyme disease is I. ricinus.

In the process of ontogeny, ixodic mites undergo three blood-sucking stages: the larva, the nymph and the imago, each of which feeds on blood before molting, or the laying of eggs by the female. It has been proven that I. ricinus larvae can become infected with $B$. afzelii through the blood of infected rodents, or through the blood of a healthy animal during a bloodbath next to an infected tick (so-called "co-feeding infection") (Feria-Arroyo et al., 2014; Voordouw, 2015; Moraes-Filho et al., 2018). Rodents are thought to be affected mainly by infected nymphs, as larvae are rarely infected and adult ticks rarely feed on rodents (Millins et al., 2017).

The likelihood of meeting the larvae with the host animal influences their survival and transformation into a nymph and further to an imago. At each phase and stage of transformation, the dependence of the parasite on the presence of an appropriate stage of development of the host, its number and activity is traced (Mannelli et al., 2012). Tick tick density (tick burdens) depends on the population size of the most common rodent species in Europe: forest mouse (Apodemus sy/vaticus), yellow-breasted mouse (Apodemus flavicollis), and field mouse (Myodes glareolus) white-footed (Peromyscus leucopus). According to the scientists of the State Institute of Epizootology of the Institute of Pedagogical Sciences of the National Academy of Sciences of Ukraine, who studied the parasitic systems of I. risinus under different cattle retention schemes, it was found that, in the conditions of pasture (camp) retention by the larvae, the larvae additionally had the following species: Lacerta agilis), yellowthroated mouse (Sy/vaemus flavicollis), subterranean (Microtus subterraneus), and large Neutys fodiens; nymphs are common to the hedgehog (Erinaceus europaeus), wild boar (Sus scrofa), mussels (Lepus europaeus). In the case of stall-grazing keeping: the main ones are rats (Rattus norvegicus), domestic mice (Mus musculus), common watering (Microtus arvalis), minor - moles (Talpa europaea); nymphs are dogs (Canis lupus familiaris), rats ( $R$. norvegicus), hedgehogs (E. europaeus). For aviary keeping: forest watering (C.glareolus), mole (T.europaea), small mouse (Micromys minutus), shrews (Columba livia, Corvus frugilegus, Passer montanus); nymph is a rat ( $R$. norvegicus).

Returning to tick borreliosis, we note the following: infected tick larvae shed and turn into infected nymphs that can transmit borreliosis to rodents and humans. Development from larva to infected nymph is a key aspect of this life cycle and affects the density of infected nymphs and the risk of Lyme disease. Given that, on average, conversion from larvae to nymphs, irrespective of borrelia infection, is only possible for $10 \%$ of surviving larvae (Sprong et al., 2018), a number of questions need further investigation. Thus, researchers (van Duijvendijk et al., 2016) showed that I. ricinus larvae can transmit B. miyamotoi in $2 \%$ of cases, and the same percentage of infection was detected in nymphal stages of ticks. This differs from the data on insignificance (0.62\%) of I. ricinus larvae, B. burgdorferi and B. afzelii, which, however, grows in $10 \%$ of nymphs. In turn, the infection of tick borne larvae depends on the affection of their populations of hosts. Studies by US scientists have found that adult pacifiers of 1. pacificus and nymphs are equally carriers of $B$. burgdorferi and $B$. miyamotoi, but nymphs have 2.5 times more infection with B. burgdorferisl than B. B. myyamotoi

It is now known that $I$. ricinus larvae can transmit $B$. afzelii to rodents, but it is not known exactly how the larvae can become infected. Theoretically, the infection of the larvae can occur transarially from the female, or while feeding on the rodent. Transovarian transmission, however, has never been proven for $B$. burgdorferi, but is an important mechanism for $B$. miyamotoi transmission (Rollend et al., 2013). At the same time, the issue of the minimum tick feeding time remains controversial in the context of pathogen transmission. It has been experimentally shown that the feeding of I. ricinus larvae on infected rodents for 8 hours rarely caused the infection of the mite with $B$. burgdorferi s.l. and did not cause the rodent to reinfect the next feed, which is obviously due to the lack of spirochetes for efficient transmission. However, an injection of 10 spirochetes is sufficient to successfully infect a rodent. The vast majority of experiments indicate that infection in vivo may occur in less than 24 hours, but its effectiveness increases with increasing tick feeding time, according to various data from 7$20 \%$ in 24 hours to $50-100 \%$ in 48 hours (Cook et al., 2015). However, it has been found that the effectiveness of infection depends not only on the feeding time of the adult tick but also on the bacterial strain (Sertour et al., 2018). Thus, it was found that strains of B. burgdorferi N40 and B31 are found in the rodent after 24 hours and $120 \mathrm{~h}$ of feeding, respectively. Infection of $B$. afzelii with JBS and PBi strains was also noted within $24 \mathrm{~h}$ of feeding. The spread of different strains of borrels in the nourishment body also has time frames, depending on the mode of transmission of the pathogen. Yes, rats in different organs were diagnosed with strain BRE-13 after $24 \mathrm{~h}$, and in the heart only $72 \mathrm{~h}$ after injection. Infection with IBS-5 strain of all organs was detected within 120 hours only. In addition, it was found that under conditions of transmission from nymphs, infection of mice with different strains of borrelia occurred in less than 12 hours. 
The density of infected nymphs changes throughout the calendar year, with the vast majority being detected in July-August). Geographically, the area is also uneven, formed under the influence of multitrophic interactions of the tick-host and has several features. For example, a tick-seeking strategy to find a successful feeder and pathogen feeder is great for different types of rodents. It has been found that the success of the search for hosts is affected by the affection of both rodents and ticks of $B$. afzelii (Millins et al., 2017). Genetic studies of the population structure of I. ricinus indicate that these ticks feed on certain hosts, that is, they select the feeder on specific grounds. In general, within the rodent population of a particular species, there is a division into individuals less attractive to acarids, with a low tick-borne burden, and more attractive individuals with a high tickborne burden (Heylen et al., 2013). This intraspecific variant of selection preference depends on the sex, age, body weight and activity of the animal. The ticks are more likely to attack males compared to females, older rodents compared to younger, larger animals compared to individuals with less body weight (however, this may be due to the fact that males are heavier than females), active rodents compared to females with less mobile animals (Taylor et al., 2013). It has been experimentally found that Dermacentor variabilis (Say, 1908) prefers the "smell" of large male mice to smaller females Dallas \& Fore, 2013).

In addition to rodents, other mammals, including ungulates (Millins et al., 2017), are important in the spread of ixodic mites. Relationships between predator populations and other vertebrates are also important (Ostfeld et al., 2018). Significant changes in the spread and dynamics of transmissible diseases are introduced by man: as a tick-dweller; as a migrant penetrating into the natural habitats of acarids; as a landscape converter. Thus, large-scale studies of Polish colleagues have found that ticks infected with $B$. burgdorferi are inhabited by all regions of Poland and, accordingly, cases are reported in these regions (Gałęziowska et al., 2018). The spread of tick-borne ticks has been variable depending on the season and region of Poland. The largest number of infected ticks was collected in the autumn (54 ticks - 69.23\%), from people who were in the forests (44 ticks - 56.41\%). Among the people who were infected with ticks, the dominant group consisted of persons over 16 years of age (53 persons $-67.95 \%$ ) and children aged 0 to 5 years (16 persons $-20.51 \%$ ).

It is now known that feeding hosts, primarily rodents and vector-borne ticks, can be simultaneously affected by several pathogens or multiple genotypes of the same pathogen. Thus, according to the reports of a wide range of scientists from the USA, Europe and Asia, simultaneous parasitic associations are known in the composition of B. burgdorferi s./ borrelia, $A$. phagocytophilum anaplasm and Babesia microti babesia (Diuk-Wasser et al., 2016). It was found that babesiosis was also found in $10 \%$ of Lyme borreliosis patients, causing a severe course of Lyme disease (Knapp \& Rice 2015).

Ixodic mites can transmit several human pathogens simultaneously, including spirochetic bacteria (B.burgdorferi $s /$ and B.miyamotol), rickettsial bacteria ( $A$. phagocytophilum), flaviviruses (tick-borne encephalitis virus) and $B$. protozoa (Babesiagensi, B. d. and B. venatorum) (Diuk-Wasser et al., 2016; Laaksonen et al., 2018).

According to scientific literature, $19.5 \%$ of ticks removed from domestic dogs and cats were found to be $A$. hagocytophilum, and $10.1 \%$ of borelia (B. afzelii, B. garinii, B. burgdorferi ss, B. lusitaniae, B. valaisiana, B. spielmanil). Rickettsia helvetica was detected in $14.1 \%$ of ixodic mites (Claerebout et al., 2013). Dogs are a kind of safety markers for their owners about the possibility of being infected with ticks, since they live largely in the same conditions and visit the same open spaces.

In the available domestic literature, there is almost no data on the phase composition of borelia infected with ixodids, by region. However, a modern meta-analysis of epizootic monitoring results indicates that across Europe, the prevalence of /.ricinus affected by Borelia is $13.7 \%$ on average, although the imago infection rate is higher than that of nymphs and is $14.9 \%$ and $11.8 \%$, in accordance. Central European countries (Austria, Czech Republic, Germany, Switzerland, Slovenia and Slovakia) have the highest rates of nymph infection, which is over $11 \%$ and over $20 \%$ in adult ticks, respectively (Strnad et al., 2017). These statistics can well be extrapolated to Ukraine. And considering that in the forests of the western forest-steppe and Polesie the occurrence index of ixodids is almost always equal to $90-100,0 \%$, and the abundance index, even in urban biotopes, can be 5-15, and more specimens / flags / km. the extent of the problem is understandable. Thus, the widespread spread of Lyme disease in Ukraine, Europe and the world determines the need for further study of both the pathogen and its vectors and possible ways of controlling them.

The geographical location of Ukraine, where the boundaries of several physical and geographical zones extend, determines the significant diversity of both free-living and parasitic invertebrates, which requires constant monitoring in today's integration conditions. Within the transboundary territories there is a need to control the agents and vectors of infectious and invasive diseases of animals and humans, to study changes in the geography of habitats of thermophilic migrant species, and to introduce systematic measures for the prevention of parasites (Gutyj et al., 2017; Holovakha et al., 2018; Kulyaba et al., 2019; Yevstafieva et al., 2019; Chernushkin et al., 2020).

\section{Conclusions}

The analysis of the literature has shown that all stages of ticks depend to a large extent on three basic natural factors: temperature, humidity and presence of the feeder. The results of epizootic monitoring and laboratory studies prove that nymphs and imago /. ricinus are equally infected with the most common infectious agents: spirochetes, rickettsiae, flaviviruses, and protozoa, with their associations being commonly observed. Given the significant epidemiological significance of ixodic ticks, more careful monitoring studies of the population of ixodic ticks are needed in biogeocenoses; to scientific institutions and departments of especially dangerous diseases of research laboratories, to introduce control of blood of migratory birds and wild vertebrates for the presence of pathogens of transmissible diseases transmitted by ixodic mites; to conduct outreach to hunters and the general public with a view to the most rational organization of preventive measures during periods of tick activity. The biological and parasitological aspects of the control of anthropozoonoses are of particular importance in the current conditions of globalization of the economy, migration of the population and in the current climate change.

References 
A kimov, I.A., \& Nebogatkin, I.V. (1997). Vidovoj sostav iksodovyh kleshhej (Acarina, Ixodidae) Ukrainy. Vestnik zoologii, 3, 75-77 (in Russian).

Berret, J., \& Voordouw, M.J. (2015). Lyme disease bacterium does not affect attraction to rodent odour in the tick vector. Parasites \& Vectors, 8(1), 249. doi: 10.1186/s13071-015-0856-8.

Cabezas-Cruz, A., Estrada-Peña, A., Rego, R.O., \& De la Fuente, J. (2017). Tick-Pathogen Ensembles: Do Molecular Interactions Lead Ecological Innovation? Frontiers in Cellular and Infection Microbiology, 13(7), 74. doi: 10.3389/fcimb.2017.00074.

Cayol, C., Jääskeläinen, A., Koskela, E., Kyröläinen, S., Mappes, T., Siukkola, A. \& Kallio, E. R. (2018). Sympatric Ixodes-tick species: pattern of distribution and pathogen transmission within wild rodent populations. Scientific Reports, 8(16660). doi:10.1038/s41598-01835031-0

Chernushkin, B.O., Vlizlo, V.V., Slivinska, L.G., Gutyj, B.V., Shcherbatyy, A.R., Maksymovych, I.A., Leno, M.I., Rusyn, V.I., Lychuk, M.H., Fedorovych, V.L., Lukashchuk, B.O., Zinko, H.O., \& Prystupa, O.I. (2020). Treatment strategies for sheep with acute yellow athrophy of the liver caused by the fasciolosis. Ukrainian Journal of Ecology, 10(2), 294-301. doi: 10.15421/2020_100.

Claerebout, E., Losson, B., Cochez, C., Casaert, S., Dalemans, A., De Cat, A., Madder, M., Saegerman, C., Heyman, P., \& Lempereur L. (2013) Ticks and associated pathogens collected from dogs and cats in Belgium. Parasites \& Vectors, 6(183) doi.org/10.1186/17563305-6-183

Cook, M.J. (2015). Lyme borreliosis: a review of data on transmission time after tick attachment. International Journal of General Medicine, 8, 1-8. doi: 10.2147/IJGM.S73791

Cotté, V., Sabatier, L., Schnell, G., Carmi-Leroy, A., Rousselle, J.C., Arsène-Ploetze, F., Malandrin, L., Sertour, N., Namane, A., Ferquel, E, \& Choumet, V. (2014) Differential expression of Ixodes ricinus salivary gland proteins in the presence of the Borrelia burgdorferi sensu lato complex. Journal of Proteomics, 96, 29-43. doi: 10.1016/j.jprot.2013.10.033.

Dallas, T., \& Fore, S. (2013). Chemical attraction of Dermacentor variabilis ticks parasitic to Peromyscus leucopus based on host body mass and sex. Experimental and Applied Acarology, 61(2), 243-250.

de la Fuente, J., Villar, M., Cabezas-Cruz, A., Estrada-Peña, A., Ayllón, N., \& Alberdi, P. (2016). Tick-Host-Pathogen Interactions: Conflict and Cooperation. PLoS Pathog, 12(4): e1005488. doi: 10.1371/journal.ppat.1005488.

Diuk-Wasser, M.A., Vannier, E., \& Krause, P.J. (2016). Coinfection by the tick-borne pathogens Babesia microti and Borrelia burgdorferi: ecological, epidemiological and clinical consequences Trends Parasitology, 32(1), 30-42. doi: 10.1016/j.pt.2015.09.008.

Erin, E., McClure, C., Wanga, X., Shawa, D. K., O’Neala, A. J., Cháveza, A. S. O., Browna, L.J., Boradiaa, V.M., Hammonda, H.L., \& Pedraa, J.H.F. (2019) p47 licenses activation of the immune deficiency pathway in the tick Ixodes scapularis Proceedings of the National Academy of Sciences, 116(1), 205-210. doi: 10.1073/pnas.1808905116.

Fedonjuk, L.Ja. Podobivs'kij, S.S., Korda, M.M., Klishh, I.M., Andrejchin, M.A., Shkil'na, M.I. (2018). Morfo-fiziologichni osoblivosti ta medichne znachennja iksodovih klishhiv rodiv Ixodes Latr. ta Dermacentor fabr.- ektoparazitiv ljudini i tvarin u Zahidnij Ukraini. Svit medicini ta biologii, 1(63), 173-177 (in Ukrainian)

Fedonuk, L.Ya. Podobivskiy, S., Kamyshnyi, A., Saturska, A., Chavtur, V., Marchuk, O., Zagrychuk, O., Furca, O., \& Chernishova, V. (2019). Morphological and physiological, biological and features of Acariana of the genus Ixodes (Latreille, 1795) - human ectoparasites in biogenocenoses of Ternopil region. Wiadomosci Lecarskie, LXXII(2), 224-229.

Feria-Arroyo, T.P., Castro-Arellano, I., Gordillo-Perez, G., Cavazos, A.L., Vargas-Sandoval, M., Grover, A., Torres, J., Medina, R.F., Pérez de León, A.A., \& Esteve-Gassent, M.D. (2014). Implications of climate change on the distribution of the tick vector Ixodes scapularis and risk for Lyme disease in the Texas-Mexico transboundary region. Parasites \& Vectors, 7, 199. doi: 10.1186/1756-3305-7-199.

Gałęziowska, E., Rzymowska, J., Najda, N., Kołodziej, P., Domża-Drzewicka, R., Rząca, M., Muraczyńska, B., Charzyńska-Gula, M., Szadowska-Szlachetka, Z., Ślusarska, B., \& Guty, E. (2018). Prevalence of Borrelia burgdorferi in ticks removed from skin of people and circumstances of being bitten - research from the area of Poland, 2012-2014. Annals of Agricultural and Environmental Medicine, 25(1), 31-35. doi: 10.5604/12321966.1233906.

Gazzavi-Rogozina, L., Tkachov, O.V., Filiptsova, O.V., Naboka, O.I, Burlaka, I.S., Dyomina, Y.V., \& Pidgaina, V.V. (2018). The method of epizootic assessment of the area of the institute writers. Scientific Messenger of LNU of Veterinary Medicine and Biotechnologies. Series: Veterinary Sciences, 20(83), 36-39. doi: 10.15421/nvlvet8307.

Gilbert, L., Aungier, J., \& Tomkins, J.L. (2014). Climate of origin affects tick (/xodes ricinus) host-seeking behavior in response to temperature: implications for resilience to climate change? Ecology and evolution, 4(7), 1186-1198. doi: 10.1002/ece3.1014.

Gutyj, B., Khariv, I., Binkevych, V., Binkevych, O., Levkivska, N., Levkivskyj, D., \& Vavrysevich, Y. (2017). Research on acute and chronic toxity of the experimental drug Amprolinsyl. Regul. Mech. Biosyst., 8(1), 41-45.

Herrmann, C., \& Gern, L. (2015). Search for blood or water is influenced by Borrelia burgdorferi in Ixodes ricinus. Parasites \& Vectors, 8, 6. doi: 10.1186/s13071-014-0526-2.

Heylen, D., Adriaensen, F., Van Dongen, S., Sprong, H., \& Matthysen, E. (2013). Ecological factors that determine Ixodes ricinus tick burdens in the great tit (Parus major), an avian reservoir of Borrelia burgdorferi s./. International Journal of Parasitology, 43(8), 603611. doi: 10.1016/j.ijpara.2013.02.007.

Holovakha, V.I., Piddubnyak, O.V., Bakhur, T.I., Vovkotrub, N.V., Antipov, A.A., Anfiorova, M.V., Gutyj, B.V., Slivinska, L.G., Kurdeko, O.P., \& Macynovich, A.O. (2018). Changes in erythrocytopoesis indices in dogs with babesiosis. Regulatory Mechanisms in Biosystems, 9(3), 379-383. doi:10.15421/021856

Jahfari, S., Ruyts, S.C., Frazer-Mendelewska, E., Jaarsma, R., Verheyen, K., \& Sprong, H. (2017). Melting pot of tick-borne zoonoses: the European hedgehog contributes to the maintenance of various tick-borne diseases in natural cycles urban and suburban areas. Parasites \& Vectors, 10, 134. doi: 10.1186/s13071-017-2065-0.

Knapp, K.L., \& Rice, N.A. (2015). Human Coinfection with Borrelia burgdorferi and Babesia microti in the United States. Journal of Parasitology Research, 2015, 587131. doi: 10.1155/2015/587131.

Korenberg, E.I., Kovalevskii, Y.V., Gorelova, N.B. \& Nefedova, V.V. (2015). Comparative analysis of the roles of Ixodes persulcatus and Ixodes trianguliceps ticks in natural foci of ixodid tick-borne borrelioses in the Middle Urals, Russia. Ticks and Tick-Borne Diseases, 6(3), 316-321.

Kotsyfakis, M., Schwarz, A., Erhart, J. \& Ribeiro, J.' M.C. (2015) Tissue- and time-dependent transcription in Ixodes ricinus salivary glands and midguts when blood feeding on the vertebrate host. Scientific Reports, 5, 9103. doi: 10.1038/srep0913. 
Kulyaba, O., Stybel, V., Gutyj, B., Turko, I., Peleno, R., Turko, Ya., Golovach, P., Vishchur, V., Prijma, O., Mazur, I., Dutka, V., Todoriuk, V., Golub, O. Dmytriv, O., Oseredchuk, R. (2019). Effect of experimental fascioliasis on the protein synthesis function of cow liver. Ukrainian Journal of Ecology, 9(4), 612-615.

Laaksonen, M., Klemola, T., Feuth, E., Sormunen, J.J., Puisto, A., Mäkelä, S, Penttinen, R., Ruohomäki, K., Hänninen J, Sääksjärvi, I.E., Vuorinen, I., Sprong, H., Hytönen, J., \& Vesterinen, E.J. (2018). Tick-borne pathogens in Finland: comparison of Ixodes ricinus and I. persulcatus in sympatric and parapatric areas. Parasites \& Vectors, 11(556). doi: 10.1186/s13071-018-3131-y.

Mannelli, A., Bertolotti, L., Gern, L., Gray, J. (2012). Ecology of Borrelia burgdorferi sensu lato in Europe: transmission dynamics in multihost systems, influence of molecular processes and effects of climate change. FEMS Microbiology Reviews. 36(4), 837-861. doi: 10.1111/j.1574-6976.2011.00312.x.

McClure, M., Diuk-Wasse, M.A. (2019) Climate impacts on blacklegged tick host-seeking behavior. International Journal for Parasitology, 49(1), 3758713147. doi: 10.1016/j.ijpara.2018.08.005.

Millins, C., Gilbert, L., Medlock, J., Hansford, K., Thompson, D.B., Biek, R., (2017). Effects of conservation management of landscapes and vertebrate communities on Lyme borreliosis risk in the United Kingdom. Philosophical transactions of the royal society Biological sciences, 372(1722). doi: 10.1098/rstb.2016.0123.

Moraes-Filho, J., Costa, F.B. Gerardi, M., Soares, H.S., \& Labruna, M.B. Rickettsia rickettsia (2018). Co-feeding Transmission among Amblyomma aureolatum. Ticks Emerging Infectious Diseases. 24(11). 2041-2048. doi: 10.3201/eid2411.180451.

Ostfeld, R. S., Brunner J. L. (2015). Climate change and Ixodes tick-borne diseases of humans. Philosophical Transactions of the Royal Society. Biological sciences, 370 (1665): 20140051. doi: 10.1098/rstb.2014.0051.

Ostfeld, R. S., Levi, T., Keesing, F., Oggenfuss, K. \& Canham C. D. (2018). Tick-borne disease risk in a forest food web. Ecology, 99(7), 1562-1573. doi: 10.1002/ecy.2386.

Padgett, K., Bonilla, D., Kjemtrup, A., Vilcins, I-M., Yoshimizu, M.H., Hui, L., Sola, M., Quintana, M., \& Kramer, V. (2014). Large Scale Spatial Risk and Comparative Prevalence of Borrelia miyamotoi and Borrelia burgdorferi Sensu Lato in Ixodes pacificus. PLoS ONE, 9(10), e110853. doi: 10.1371/journal.pone.0110853.

Popitsch, N., Bilusic, I., Rescheneder, P., Schroeder, R., \& Lybecker M. (2017). Temperature-dependent sRNA transcriptome of the Lyme disease spirochete. BMC Genomics, 18, 28. doi: 10.1186/s12864-016-3398-3.

Remesar, S., Fernández, P.D., Vensal, J. M., Creo, A.P., Prieto, A., Estrada-Peña, A., López, C. M., Panadero, R., Fernández, G., Díez-Baños, P. \& Morrondo P. (2019). Tick species diversity and population dynamics of Ixodes ricinus in Galicia (north-western Spain). Ticks and Tick-borne Diseases, 10(1), 132-137. doi: 10.1016/j.ttbdis.2018.09.006p.

Rollend, L., Fish, D., \& Childs, J.E. (2013). Transovarial transmission of Borrelia spirochetes by Ixodes scapularis. a summary of the literature and recent observations. Ticks Tick Borne Diseases, 4(1-2), 46-51. doi: 10.1016/j.ttbdis.2012.06.008.

Romashchenko, A.V., Ratushnyak, A.S., Zapara, T.A., Tkachev, S.E., \& Moshkin, M.P. (2012). The correlation between tick (/xodes persulcatus Sch.) questing behavior and synganglion neuronal responses to odours. Journal of Insect Physiology, 58(7), 903-910. doi: 10.1016/j.jinsphys.2012.04.004.

Rosendale, A.J., Dunlevy, M.E., Fieler, A.M., Farrow, D.W., Davies, B., \& Benoit, J.B. (2017). Dehydration and starvation yield energetic consequences that affect survival of the American dog tick. Journal of Insect Physiology, 101, 39-46. doi: 10.1016/j.jinsphys.2017.06.012.

Sertour N., Cotté, V., Garnier, M., Malandrin, L., Ferquel, E., \& Choumet, V. (2018). Infection Kinetics and Tropism of Borrelia burgdorferi sensu lato in Mouse After Natural (via Ticks) or Artificial (Needle) Infection Depends on the Bacterial Strain. Frontiers in Microbiology, 9(1722), 1-11. doi: 10.3389/fmicb.2018.01722.

Sprong, H., Azagi, T., Hoornstra, D., Nijhof, A. M., Knorr, S., Baarsma M. E. \& Hovius, J.W. (2018). Control of Lyme borreliosis and other Ixodes ricinus-borne diseases. Parasites \& Vectors, 11(1), 145. doi: 10.1186/s13071-018-2744-5.

Strnad, M., Hönig, V., Ružek, D., Grubhoffer, L., \& Rego ROM. (2017). Europe-wide meta-analysis of Borrelia burgdorferi sensu lato prevalence in questing Ixodes ricinus ticks. Appl Environ Microbiol, 83(15), doi: 10.1128/AEM.00609-17.

Taylor, K.R., Takano, A., Konnai, S., Shimozuru, M., Kawabata, H., \& Tsubota, T. (2013). Differential tick burdens may explain differential Borrelia afzelii and Borrelia garinii infection rates among four, wild, rodent species in Hokkaido Japan. Journal of Veterinary Medicine Science, 75(6), 785-790.

van Duijvendijk, G., Coipan, C., Wagemakers, A., Fonville, M., Ersöz, J., Oei, A., Földvári, G., Hovius, J., Takken, W., \& Sprong H. (2016). Larvae of Ixodes ricinus transmit Borrelia afzeliiand Borrelia miyamotoi to vertebrate hosts. Parasites \& Vectors, 9, 97. doi: 10.1186/s13071-016-1389-5.

van Duijvendijk, G., Sprong, H., \& Takken, W. (2015). Multi-trophic interactions the transmission cycle of Borrelia afzelii between Ixodes ricinus and rodents: a Review. Parasites \& Vectors, 8, 643. doi: 10.1186/s13071-015-1257-8.

van Duijvendijk, G., Gort, G., Sprong, H., \& Takken, W. (2017). Behavioural responses of Ixodes ricinus nymphs to carbon dioxide and rodent odour. Medical and Veterinary Entomology, 31(2), 220-223. doi: 10.1111/mve.12214.

Voordouw, M.J. (2015) Co-feeding transmission in Lyme disease pathogens. Parasitology, 142(2), 290-302. doi: $10.1017 / \mathrm{S} 0031182014001486$

Yevstafieva, V.A., Kravchenko, S.O., Gutyj, B.V., Melnychuk, V.V., Kovalenko, P.N., \& Volovyk, L.B. (2019). Morphobiological analysis of Trichuris vulpis (Nematoda, Trichuridae), obtained from domestic dogs. Regulatory Mechanisms in Biosystems, 10(2), 165-171. doi: $10.15421 / 021924$

\section{Citation:}

Fedonyuk, L.Ya., Pryvrotska, I.B., Podobivskyi, S.S., Rujytska, O.Yu., Stravskyy, Ya.S., Zhyhalyuk, S.V. (2020). Ticks of genus Ixodidae: bioecological mechanisms of adaptation to environmental conditions, medical and epidemiological significance. Ukrainian Journal of Ecology, 1066), 236-242.

This work is licensed under a Creative Commons Attribution 4.0. License 